\title{
A Neonatal Case of Phacomatosis Pigmentovascularis Type IIa
}

\author{
Ezgi Ünlü, Tijen Şahin
}

Department of Dermatology, Zekai Tahir Burak Women's Health Training and Research Hospital, Ankara, Turkey

A 2-day- old male newborn was consulted to our clinic for cutaneous vascular and pigmentary lesions. The pregnancy of his mother and family history were unremarkable. Physical examination showed bilateral nevus flammeus involving the scalp, face, neck, trunk, upper part of the back, scrotum and the flexor sides of arms and thighs. Large, bluish-grey pigmentation was observed on the abdominal area, back, buttocks, legs and the extensor sides of the arms (Figure 1a, b). Laboratory examination, abdominal ultrasound imaging and magnetic resonance imaging of the brain were normal. Sys- temic involvement was not detected. Phacomatosis pigmentovascularis (PPV) type IIa was diagnosed.

Phacomatosis pigmentovascularis is a rare disorder characterized by the coexistence of vascular malformations and pigmentary lesions of skin. The first description of the disease was reported by Ota et al. (1), and Hasegawa et al. (2) classified the disease into four types. Nevus flammeus was the constant vascular malformation for all types. The associated pigmentary lesions were nevus pigmentosus et verrucosus in type I, Mongolian spots with or without nevus anemicus in
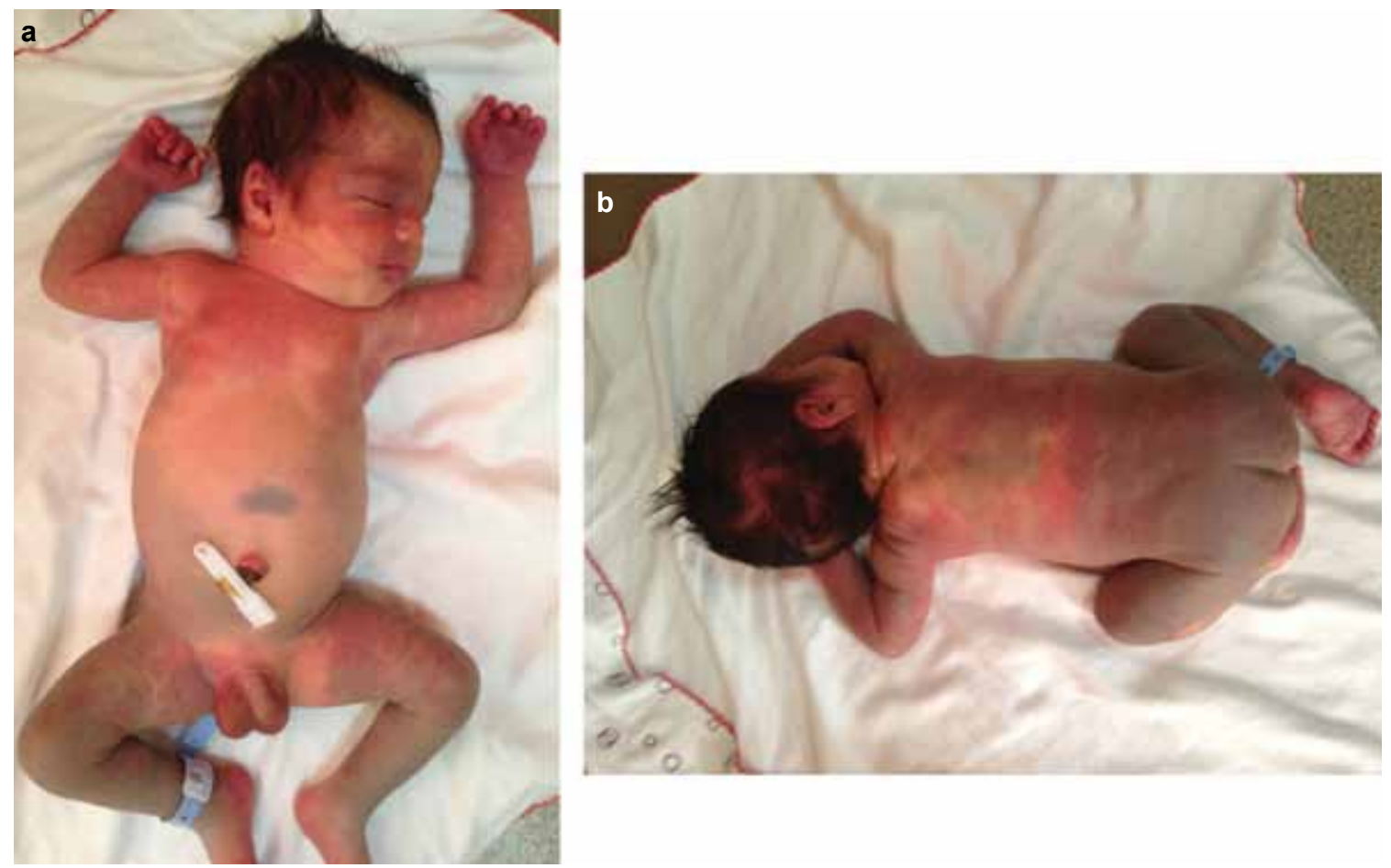

FIG. 1. a, b. Bilateral nevus flammeus involving the scalp, face, neck, trunk, scrotum and the flexor sides of arms and thighs (a). Large, bluish-gray pigmentation on the back, buttocks, legs and the extensor sides of arms (b)

This manuscript was presented as a poster at the $6^{\text {th }}$ National Pediatrics Dermatology Congress, 17-20 April, 2014, Cyprus.

Address for Correspondence: Dr. Ezgi Ünlü, Department of Dermatology, Zekai Tahir Burak Women's Health Training and Research Hospital, Ankara, Turkey Phone: +905326656087 e-mail: drezgiyalcin@yahoo.com

Received: 27.05.2014 Accepted: 12.08.2014 • DOI: 10.5152/balkanmedj.2015.15448

Available at www.balkanmedicaljournal.org

Ünlü E, Şahin T. A neonatal case of phacomatosis pigmentovascularis type IIa.

Balkan Med J 2015;32:129-30. 
type II, nevus spilus with or without nevus anemicus in type III and both nevus spilus and Mongolian spots with or without nevus anemicus in type IV. Also, each type was classified into two subtypes based on the absence or presence of systemic involvement. Subtype 'a' had only oculocutaneous involvement, while ' $b$ ' had systemic findings $(1,2)$. Torrelo et al. (3) observed the coexistence of cutis marmorata telangiectatica congenita (CMTC) and Mongolian spots in two cases and reported this association as PPV type V. Happle et al. (1) proposed a new classification and renamed PPV type II as phacomatosis cesioflammea, PPV type III as phacomatosis spilorosea and PPV type $\mathrm{V}$ as phacomatosis cesiomarmorata. Other rare associations were called unclassifiable PPV.

Type II is the most common form of the disease, with 50\% of cases having systemic involvement (1). Sturge-Weber and Klippel-Trenaunay syndromes are the most common disorders associated with PPV (4). Cerebral atrophy, Arnold-Chiarri type I, bilateral deafness, idiopathic facial paralysis, hydrocephalia, diabetes insipidus, plexiform neurofibroma, delay in psychomotor development, epilepsy, melanosis oculi, iris hamartomas, glaucoma, chronic corneal oedema, prominent vessels in sclera, pigmentary alternations in retina, cataract, leg-length discrepancy, scoliosis, spinal dysraphism, hemihypertrophy, syndactilia, macrocephalia, renal agenesia, renal angiomatosis, hepatosplenomegaly, umbilical hernia, hypoplasia of leg veins, IgA deficiency, hyper IgE syndrome, colonic polyposis, subglottic stenosis, hypoplastic larynx, and multiple granular cell tumours have been reported as isolated cases and are thought to be incidental findings $(1,2)$.

The most common skin manifestation of PPV is nevus flammeus. Pigmentary lesions include Mongolian spots, nevus of Ota and Ito. Other reported skin disorders are nevus anemicus, nevus spilus, cafe-au-lait spots, generalised vitiligo and congenital triangular alopecia (1).

Cutaneous lesions may spontaneously regress with age, but the patients usually require laser therapy for cosmetic problems. Pulsed dye laser has been used for nevus flammeus and Q-switched lasers have been preferred for the treatment of pigmentary lesions (5).

\section{Ethics Committee Approval: N/A.}

Informed Consent: Written informed consent was obtained from the patient's father for the publication of this case report and any accompanying images.

Peer-review: Externally peer-reviewed.

Author contributions: Concept - E.U., T.S.; Design - E.U., T.S.; Supervision - E.U., T.S.; Resource - E.U., T.S.; Materials - E.U., T.S.; Data Collection\&/or Processing - E.U., T.S.; Analysis\&/or Interpretation - E.U., T.S.; Literature Search - E.U., T.S.; Writing - E.U., T.S; Critical Reviews - E.U., T.S.

Conflict of Interest: No conflict of interest was declared by the authors.

Financial Disclosure: The authors declared that this study has received no financial support.

\section{REFERENCES}

1. Fernández-Guarino $\mathrm{M}$, Boixeda $\mathrm{P}$, de Las Heras E, Aboin S, Garcia-Millán C, Olasolo PJ. Phacomatosis pigmentovascularis: Clinical findings in 15 patients and review of the literature. $\mathrm{J} \mathrm{Am}$ Acad Dermatol 2008;58:88-93. [CrossRef]

2. Seckin D, Yucelten D, Aytug A, Demirkesen C. Phacomatosis pigmentovascularis type IIIb. Int J Dermatol 2007;46:960-3. [CrossRef]

3. Torrelo A, Zambrano A, Happle R. Cutis marmorata telangiectatica congenita and extensive mongolian spots: type 5 phacomatosis pigmentovascularis. Br J Dermatol 2003; 148:342-5. [CrossRef]

4. Diociaiuti A, Guidi B, Aguilar Sanchez JA, Feliciani C, Capizzi R, Amerio P. Phacomatosis pigmentovascularis type IIIb: a case associated with Sturge-Weber and Klippel-Trenaunay syndromes. J Am Acad Dermatol 2005;53:536-9. [CrossRef]

5. Adachi K, Togashi S, Sasaki K, Sekido M. Laser therapy treatment of phacomatosis pigmentovascularis type II: two case reports. J Med Case Rep 2013;7:55. [CrossRef] 